\title{
Immune responses in persistent virus infections
}

\author{
A. C. Allison \\ From the Clinical Research Centre, Harrow, Middlesex
}

Persistent virus infections either show steady and relentless progress-scrapie, visna, or maedi-or persistence with reactivation, as does varicella-zoster. In either case host defence mechanisms are unable to control the infection. To understand the underlying defects it is necessary to know what limits the progress of virus infections under normal conditions. Several factors contribute to host resistance against viruses, and it is becoming apparent that their relative importance varies from one virus infection to another. The main findings will be reviewed in this paper, together with available observations on immune responses to persistent viruses. The simplest way to achieve progressive infections is for the agent responsible to be non-immunogenic, and this, as far as we know, is true of scrapie and related agents. Speculations on why immune responses are ineffective in other persistent virus infections can be offered. Immunopathological reactions to virus infections are also attracting current interest. Since they contribute to the lesions observed in persistent virus infections, they are also briefly considered in this paper.

\section{Mechanisms of Resistance against Viruses}

The term 'immunity' can be used in a broad sense to describe any form of resistance against a potentially pathogenic organism or toxin. Immunity against viruses has many components, including resistance of individual host cells to infection, local factors such as temperature or acidity, formation of interferon, resistance of macrophages and other leucocytes, and specific humoral and cell-mediated immune responses. The situation is obviously complex, but my colleagues and I have been attempting to find out whether it is possible to show that in particular virushost combinations some resistance factors are more important than others.

We have used several techniques to eliminate one or more resistance factors. Unfortunately, none of the available immunosuppressive techniques is sufficiently selective to give unambiguous information by itself. Even neonatal thymectomy and administration of antilymphocytic serum (ALS), pro- cedures that powerfully suppress cell-mediated immunity, also decrease antibody production, especially where cooperation of thymus-dependent (T) with antibody-producing (B) cells is required for an efficient response, which is the case with some viral antigens. It is therefore necessary to examine the effects of selective restoration of immune responses in immunosuppressed animals. Passive protection by serum antibody provides highly suggestive evidence that antibody can provide the critical factor controlling an infection. If antibody alone provides no protection but transfer of specifically sensitized lymphoid cells does protect, this is strong evidence that cell-mediated immunity plays a major defensive role-although extravascular production of IgM or of cytophilic antibody in recipients could be involved.

The results of animal experiments complement remarkably well observations which have been made on human patients with immunodeficiency syndromes. Although there are many gaps in knowledge, a general picture is emerging. The first major line of defence is the inherent resistance of cells at the primary site of infection; this enables cells to overcome exposure to most viruses from other species and, where there are individual inherited differences, to certain homologous viruses also. With infections of seromucous surfaces such as the respiratory or alimentary tracts, the major second line of defence is secretory antibody, which is synthesized and released locally.

Frequently viruses spread from local sites of multiplication to macrophages, which may be local (eg, alveolar or subcutaneous) or lining the sinuses of lymph nodes, liver, and spleen. Macrophages provide an important barrier to the spread of virus infections; this barrier is ineffective in very young animals and in certain mature animals with inherited susceptibility to particular virus infections. The third major defence system is circulating antibody, which frequently limits spread of viruses through the blood stream and their multiplication in target organs such as the brain, liver, or heart. Serum antibody is effective against many viruses, but some-such as herpesviruses, poxviruses and certain myxoviruses-can spread despite the presence of 
antibody; cell-mediated immunity plays an important protective role in these cases. It is of interest that several slow virus diseases fall into this category. Whether interferon plays a significant role in defence under conditions of natural infection is still unknown although it can limit virus multiplication under certain rather special conditions. High temperatures can protect susceptible hosts from some virus infections. Interactions of these factors have recently been reviewed (Allison, 1972a). In this paper comments will be restricted to circulating antibodies and cell-mediated immunity, defects of which are probably most relevant to slow virus infections.

\section{CIRCULATING ANTIBODY}

Circulating antibody has long been regarded as a major defence mechanism against virus infections, and evidence which has accumulated during the past few years supports this interpretation for most viruses that produce systemic as opposed to local (seromucous surface) infections. The most direct evidence comes trom the use of immunosuppressive agents, such as cyclophosphamide, which can convert infections that are normally well tolerated into lethal infections. An example from the work of B. Zisman and myself is shown in Table I. Infection

\begin{tabular}{llc}
\hline Group & Number & $\%$ Mortality \\
\hline $\begin{array}{l}\text { Untreated control } \\
\begin{array}{l}\text { Cyclophosphamide (72 hr after } \\
\text { virus) }\end{array}\end{array}$ & 16 & 0 \\
$\begin{array}{l}\text { Cyclophosphamide + antibody } \\
\text { (4 and 15 days after virus) }\end{array}$ & 16 & 100 \\
\hline
\end{tabular}

Table I Mortality of adult CBA mice after intraperitoneal injection of Coxsackie B-3 virus (Zisman and Allison, unpublished)

with Coxsackie B virus kills newborn mice but not adult mice, unless they are immunosuppressed with cyclophosphamide. Then a high and persisting viraemia is found, together with large amounts of virus in target organs, including the heart and pancreas, and the animals die of myocarditis and pancreatitis. Administration of serum antibody to the immunosuppressed mice as late as four days after virus infection markedly reduces the amounts of virus in the blood stream and target organs and protects the mice. Interferon levels parallel the concentration of virus in the circulating blood and are highest in mice destined to die, so it seems unlikely that interferon plays a major protective role.

We have also analysed the relative roles of macrophages and antibody in defence of adult mice against yellow fever virus infection (Zisman, Wheelock, and Allison, 1971). Silica particles are selectively taken up by macrophages and damage them. Intravenous injection of yellow fever virus in adult mice is well tolerated, but the same injection after administration of silica particles results in a lethal virus encephalitis. This can be prevented by passive administration of antibody as late as 48 hours after infection. Studies with fluorescent antibodies showed that by 48 hours there were foci of virus infection in the brain, so that antibody must have been able to control infection even at that stage. This is not surprising, since antibody is known to protect against the effects of intracerebral inoculation of many viruses, including arthropod-borne viruses like yellow fever virus (Nathanson and Cole, 1970).

Observations on increased severity of many virus infections of the central nervous system following immunosuppression have been reviewed by Nathanson and Cole (1970), eg, paralytic disease produced by Japanese B encephalitis virus in spider monkeys (Ateles) treated with cyclophosphamide. Similarly Zlotnik, Smith, Grant, and Peacock (1970) found that cyclophosphamide altered the pathological picture of virus encephalitis and greatly increased central nervous system damage produced by arboviruses in monkeys that were normally resistant. There was little mononuclear reaction-which normally produces the characteristic perivascular cuffing - but neuronal necrosis and spongy degeneration were prominent.

Weiner, Cole, and Nathanson (1971) administered cyclophosphamide to mice after immunization with inactivated arboviruses to induce specific unresponsiveness. The capacity of the mice to produce antibody against the same arboviruses, administered shortly afterwards as a live challenge, was abolished and the animals died after extraneural inoculation, although they made antibody against other viruses and survived extraneural challenge. These experiments demonstrate the immunological specificity of the reaction, although they do not distinguish between a role of antibody and of cell-mediated immunity.

The observations which have been reviewed in this section suggest that with enterovirus and arthropodborne virus infections circulating antibody plays an important protective role, limiting the spread of viruses from the primary site of infection to highly susceptible target organs, such as the brain and heart, and the multiplication of viruses in those organs. Evidence that this may also be true in man comes from observations that children with severe hypogammaglobulinaemia but intact cell-mediated immunity are more liable to develop paralytic poliomyelitis after exposure to vaccine strains than are normal children (Table II). The importance of circulating antibody in preventing the spread of polio- 


\begin{tabular}{|c|c|c|}
\hline Immunodeficiency & $\begin{array}{l}\text { Virus Infection } \\
\text { Aggravated }\end{array}$ & Reference \\
\hline $\begin{array}{l}\text { Hypogammaglobulin- } \\
\text { aemia with intact } \\
\text { cell-mediated } \\
\text { immunity }\end{array}$ & $\begin{array}{l}\text { Paralytic } \\
\text { poliomyelitis }\end{array}$ & Schur et al (1970) \\
\hline \multirow{5}{*}{$\begin{array}{l}\text { Deficient cell- } \\
\text { mediated immunity } \\
\text { ( } \pm \text { normal immuno- } \\
\text { globulins) }\end{array}$} & Vaccinia & $\begin{array}{l}\text { Fulginiti et al (1968) } \\
\text { O'Connell et al (1964) }\end{array}$ \\
\hline & Herpes simplex & $\begin{array}{l}\text { Cooper et al (1968) } \\
\text { Kretschner et al (1969) }\end{array}$ \\
\hline & Varicella zoster & $\begin{array}{l}\text { Hayes et al (1965) } \\
\text { Lux et al (1969) }\end{array}$ \\
\hline & $\begin{array}{l}\text { Cytomegalo- } \\
\text { virus }\end{array}$ & $\begin{array}{l}\text { Miller and Schieken (1967) } \\
\text { Haworth et al (1967) } \\
\text { Cooper et al (1968) }\end{array}$ \\
\hline & Measles & $\begin{array}{l}\text { Nahmias et al (1967) } \\
\text { Cooper et al (1968) }\end{array}$ \\
\hline
\end{tabular}

Table II Virus infections increased in severity in human patients with different types of immunodeficiency

virus from the gut to the central nervous system accounts for the efficacy of killed virus vaccines. Neonatal thymectomy does not increase the susceptibility of mice to enterovirus infections, in contrast to herpesvirus or poxvirus infections, as discussed in the next section (Table III).

\section{CELL-MEDIATED IMMUNITY}

Evidence that viruses can elicit cell-mediated immune responses has been summarized elsewhere (Allison, 1972b). This is shown by the usual criteria, including delayed hypersensitivity following intradermal injection of purified virus (although there is usually an acute allergic reaction as well), transfer of reactions to non-sensitized recipients by cells but not by serum, stimulation of lymphocyte transformation in the presence of virus-infected cells, and the liberation of macrophage migration inhibitory factor. Although work on cell-mediated immunity has been much less systematic than that on antibody, there is no reason to doubt that cell-mediated immune responses are elicited at least by those viruses with antigens that infiltrate the plasma membranes of infected cells, eg, poxviruses, herpesviruses, myxoviruses, and tumour-inducing viruses.

There are at least three ways in which cellmediated immunity could confer protection against viruses. Transformation of lymphocytes into blast cells by viral and other antigens leads to the production of interferon (Glasgow, 1970). A cell-mediated immune reaction against a viral or heterologous antigen is associated with macrophage 'activation'an increase in the content of lysosomal enzymes and capacity to kill intracellular parasites, including viruses. Finally, cells in which viruses are growing bear viral antigens on their surfaces, and these can be recognized by sensitized lymphocytes which attack and destroy the cells, thereby interrupting the cycle of virus multiplication. This is discussed further in the section on immunopathology. However, lymphocyte transformation may also work against the host : many viruses cannot grow in small lymphocytes unless they are transformed by phytohaemagglutinin or an immune reaction (Bloom, Jimenez, and Marcus, 1970).

If cell-mediated immunity plays a protective role in virus infections of experimental animals, thymectomy and/or treatment with antilymphocytic serum (ALS) should aggravate the disease. Human patients with hypogammaglobulinaemia but intact cell-mediated immunity should not suffer from severe infections with these viruses, whereas in patients with defective cell-mediated immunity infections should be severe and often progressive.

Experiments on increasing severity of virus infections by thymectomy and ALS are summarized in Table III. It will be seen that the infections aggravated by these procedures are due to herpesvirus and poxviruses, whereas arbovirus and enterovirus infections are not increased in severity. This is consistent with the view that circulating antibody can limit enterovirus and arbovirus infections, whereas cell-mediated immunity is required for resolution of poxvirus and herpesvirus infections.

\begin{tabular}{llllc}
\hline Virus & $\begin{array}{l}\text { Age } \\
\text { (weeks) }\end{array}$ & $\begin{array}{l}\text { No. of } \\
\text { Mice }\end{array}$ & Treatment & $\begin{array}{l}\% \\
\text { Mortality }\end{array}$ \\
\hline Herpes simplex & 4 & 25 & NRS & 0 \\
& & 14 & $\begin{array}{l}\text { Thymectomy } \\
71\end{array}$ \\
Yellow fever & 4 & 13 & ALS & 100 \\
& & 58 & None & $16 \cdot 4$ \\
Coxsackie B-3 & 6 & 24 & ALS & 16.6 \\
& & 25 & None & 0 \\
Ectromelia & Young & 26 & Thymectomy & 0 \\
(Blanden, 1970) & adults & 26 & ALS & 20 \\
\hline
\end{tabular}

Table III Effect of suppression of cell-mediated immunity on virus infections of mice (Zisman and Allison, unpublished)

NRS $=$ normal rabbit serum; ALS $=$ rabbit antimouse-lymphocyte serum

As summarized in Table II, patients with uncomplicated severe hypogammaglobulinaemia recover normally from vaccination against smallpox and from measles and varicella infections. Congenital abnormalities in which defective cell-mediated immunity is prominent include ataxia-telangiectasia, Swiss agammaglobulinaemia, and the syndromes of 
Wiskott-Aldrich, Gitlin, Nezelof, and di George. In all these, virus infections are a recurring and often fatal complication. Fulginiti, Kempe, Hathaway, Pearlman, Sieber, Eller, Joyner, and Robinson (1968) described progressive vaccinia in patients with many of these syndromes, particularly Nezelof's syndrome in which immunoglobulin levels and specific antibody-synthesizing capacity are near normal. Patients with the Wiscott-Aldrich syndrome are particularly susceptible to infections produced by cytomegalovirus, measles, and especially herpes simplex viruses (Cooper, Chase, Lowman, Krivit, and Good, 1968). Patients with cartilage-hair hypoplasia, which is associated with a defect of cell-mediated immunity but normal antibody levels, have unusually severe varicella infections (Lux, Johnston, August, Say, Penchaszadeh, Rosen, and McKusick, 1969).

Hodgkin's disease and some other debilitating diseases, cancer chemotherapy, and immunosuppressive therapy after renal homografting, all of which depress cell-mediated to a greater extent than humoral immunity, increase susceptibility to infections, particularly by cytomegalovirus (Craighead, 1969), herpes simplex virus (Montgomerie, Becroft, Croxson, Doak, and North, 1969) and zoster, as discussed further below.

\section{Immunopathology of Virus Infections}

Although in most circumstances immunological reactions are beneficial, they sometimes initiate or aggravate tissue damage. Viruses may produce pathological changes in several ways, some of which are independent of immune reactions. Viruses may directly damage cells or tissues, they may bring about hyperplasia or malignancy, or they may more or less selectively inhibit cell division, eg, picodnaviruses. Nevertheless, it is likely that immune reactions frequently make some contribution to pathological changes observed in virus infections, as well as playing a major part in recovery. Some virus infections, such as lymphocytic choriomeningitis (LCM), produce little or no tissue damage unless accompanied by an immune response; immunopathological reactions may then be so severe as to kill the infected animal.

Cells infected with viruses may develop new surface antigens and thus become targets for antibody or cell-mediated immune reactions. These are viral envelope antigens in the case of myxo-, paramyxo-, rhabdo-, areno-, toga-, and leuco-viruses which mature by budding from the cell surface. Virus-specific antigens may also appear on the surface of cells infected with certain non-budding viruses such as poxviruses and herpes viruses, and cells transformed by viruses may bear tumour-specific transplantation antigens. In addition host-specified antigens of embryonic, Forssman, or blood-group type may appear on the surface of infected cells and induce immune responses.

For purposes of analysis, immunopathological reactions can be considered in three main classes: (1) reactions mediated by antibodies against infected cells; (2) reactions mediated by immune cells against virus-specific antigens; (3) reactions due to immune complexes consisting of antibody and virus-specific antigen. In addition, viruses may participate in the development of autoimmune reactions.

ANTIBODY-MEDIATED IMMUNOPATHOLOGICAL REACTIONS

The strongest evidence that antiviral antibody and complement can injure virus-infected cells comes from experiments in vitro. It has been shown that infection of cells with viruses that do not produce cytopathology (rabies or LCM) or with viruses that eventually do produce cytopathology (herpes simplex, vaccinia, influenza, and Newcastle disease viruses) results in the appearance of new antigens on the surface of the infected cells and that the interaction of specific antiviral antibody and complement with these antigens can damage the cells (Wiktor, Kuwert, and Koprowski, 1968; Brier, Wohlenberg, Rosenthal, Mage, and Notkins, 1972). In the absence of either specific antiviral antibody or complement, such injury does not take place. The degree of immunological injury may be influenced by a number of factors including the density of viral antigens on the surface of infected cells; the inherent susceptibility of the cells to lysis by complement; the concentration and nature of the antiviral antibody, ie, complement-fixing vs. non-complement-fixing; and the ratio of cytolytic to non-cytolytic antibody in a particular serum. Other factors, such as the phase of the mitotic cycle or coinfection with a second virus, might influence the appearance of viral antigens and effects of antibody on cells. If a particular virus produces few antigenic sites or if these sites are widely separated, complement-mediated cell destruction may not occur. Increased density of virus-specific antigens on the cell surface would enhance the likelihood of doublet formation with IgG antiviral antibody and this in turn might increase the amount of complement-mediated cell destruction. Fluctuations in the density of viral antigens on the surface of infected cells might be a particularly important factor in the pathogenesis of slow viruses. Exposure to small amounts of antiviral antibody or to non-complement-fixing antibody might result in endocytosis of membrane containing viral antigen, a process termed antigenic modulation (see Taylor, Duffus, Raff, and de Petris, 1971). 
The attachment of antibody to the surface of the infected cell might have other consequences. On the one hand, the attachment of antiviral antibody might accelerate killing or phagocytosis of the infected cell by activated macrophages. On the other hand, antiviral antibody or antigen-antibody complexes might prevent sensitized lymphocytes from recognizing or reacting with the viral antigens and thereby inhibit the cell-mediated immune response. In virus infections, this might prove to be the counterpart of 'blocking antibody' or 'immunological enhancement', favouring virus persistence.

Under certain circumstances the destruction of virus-infected cells by antiviral antibody and complement may be more beneficial than harmful to the host. Antibody-mediated cell damage may be one of the mechanisms by which the host resists those viruses that avoid neutralization by spreading directly from cell to cell. Destruction of cells which are producing virus would inhibit virus replication and release or expose the infectious virus within the cell to neutralizing antibody. Thus, in viral infections, antibody-mediated cell destruction might fulfil part of the role that has been postulated for cell-mediated immunity and may serve as a complementary or supplementary defence mechanism.

In vivo evidence that antibody plays a role in the pathogenesis of virus infections is less convincing. Depletion of complement by cobra venom decreased the lethal effects of LCM in adult mice, and injections of antibody into the cerebrospinal fluid of LCM carrier mice produced meningeal inflammation (Oldstone and Dixon, 1970). However, in mice carrying LCM after adult infection with administration of cyclophosphamide (Cole, Gilden, Monjan, and Nathanson, 1971) administration of antibody did not produce disease. When mice infected with Langat virus (an arbovirus) were given antibody, some aggravation of disease was reported (Webb, 1969). However, the timing of the antibody administration was critical, and it seems likely that antibody usually protects the host rather than increasing the severity of virus infections.

\section{CELL-MEDIATED IMMUNOPATHOLOGY}

The most fully studied laboratory model for cellmediated immunopathology has been LCM virus infection of mice. In adult mice with LCM there is virus replication in many tissues, including the viscera and the meninges. The infection is noncytopathic, and mice remain well until the onset of an immune response five to seven days after infection, when inflammatory cell infiltrations occur in the sites of viral growth in viscera and in the meninges leading to pathological changes, sickness, and death. If the immune response is inhibited by neonatal thymectomy, irradiation, antilymphocytic serum, or cytotoxic drugs, mice remain well in spite of extensive infection. In contrast, mice infected neonatally or congenitally show widespread infection with virus, but only a slight immune response to infection. They remain well during most of their life, but slowly accumulate immune complexes in kidney glomeruli, as described in the next section.

Attempts have been made to determine whether the antibody- or cell-mediated component of the immune response causes the pathological changes in mice infected as adults with LCM virus. In vivo experiments were carried out by Cole and Nathanson, who gave cyclophosphamide to adult mice infected with LCM virus. The immune response was inhibited and a persistent nonpathogenic infection established. When immune spleen cells were inoculated into these mice acute pathological changes and death were seen, comparable to those occurring in the natural infection. The transfer of immune serum was ineffective, and it was concluded that the transferred cells had reacted with infected host cells to give a cell-mediated immunopathological disease. In contrast to these results, transfer of immune spleen cells to congenitally infected carrier mice has failed to give any clinical or histological evidence of tissue damage. High titres of neutralizing and complementfixing antibody were produced in the recipient carrier mice, so that under these circumstances antibody, too, was not pathogenic (Lehmann-Grubbe, 1971).

In-vitro systems have been used to demonstrate the action of sensitized lymphoid cells on virusinfected cells. Spleen cells obtained from immune animals added to cells persistently infected with measles or mumps virus were found to destroy the latter (Speel, Osborn, and Walker, 1968). In the case of mumps virus, the cytotoxic action of the immune spleen cells could be prevented by pretreatment of target cells with antibody. Damaging effects of sensitized lymphocytes on cells carrying LCM virus have also been reported (Lundstedt, 1969; Oldstone and Dixon, 1969), but the results have not been consistent or reproducible.

Sensitized lymphocytes, after reacting specifically with viral antigen in tissues, release a variety of mediators. These mediators bring about retention and activation of macrophages in the affected area. Activated macrophages show increased capacity to take up and kill various organisms, including viruses, protozoa, and bacteria. They may also kill intact cells bearing viral antigens on their surfaces. In this way the recruited macrophages, perhaps with the help of cell-bound antibody, appear to play a major antiviral role in the infected area. At the same time they can contribute to the production of lesions. 
IMMUNOPATHOLOGICAL EFFECTS OF ANTIGENANTIBODY COMPLEXES

It is well known that persistence of antigen-antibody complexes in the circulation can lead to symptoms of serum sickness, including glomerulonephritis, vasculitis, skin rash, arthralgia, and arthritis. Recently it has been shown in animals that viruses can persist in the circulation in the form of virusantibody complexes, and that the deposition of these complexes in the kidney can lead to the development of an immune-complex type of glomerulonephritis.

Infectious virus-antibody complexes have been found in the circulation of animals infected with lactic dehydrogenase virus, Aleutian mink disease, murine leukaemias, and probably equine infectious anaemia (Table IV). Glomerulonephritis has been

\begin{tabular}{llll}
\hline Virus & $\begin{array}{l}\text { Infectious Virus } \\
\text { Ab Complexes in Complexes }\end{array}$ & $\begin{array}{l}\text { Glomerular } \\
\text { Circulation }\end{array}$ & $\begin{array}{l}\text { Complexes } \\
\text { in Walls }\end{array}$ \\
\hline $\begin{array}{lll}\text { Lymphocytic } \\
\text { choriomeningitis }\end{array}$ & + & ++ & $?$ \\
$\begin{array}{lll}\text { Aleutian mink disease } \\
\text { Murine leukemogenic }\end{array}$ & + & ++ & ++ \\
$\begin{array}{lll}\text { Equine infectious } \\
\text { anaemia }\end{array}$ & + & - \\
Human hepatitis & + & + & - \\
Lactic dehydrogenase & + & + & + \\
\hline
\end{tabular}

Table IV Presence of complexes of viral antigen and antibody in circulating blood, renal glomeruli, and blood vessel walls

demonstrated in each of these diseases, but with varying degrees of severity. In all cases viral antigen, specific antiviral antibody, and complement have been found in the kidney. Severe glomerulonephritis has been found in LCM chronic carrier mice. The degree of glomerulonephritis depends on the strain of the mouse, the amount of LCM virus, and the amount of antiviral antibody. A high proportion of the immunoglobulin eluted from diseased kidneys is antibody to LCM (Oldstone and Dixon, 1971). Aleutian disease of mink is also characterized by a severe glomerulonephritis. All mink appear to be susceptible to the virus but those homozygous for the Aleutian gene suffer the most severe disease with heavy deposition of virus, antibody, and complement in the glomeruli (Porter, Larsen, and Porter, 1969).

In contrast, lactic dehydrogenase virus, in which there is a persistent high viraemia, produces only mild renal disease (Porter and Porter, 1971) and no vasculitis. In Aleutian mink disease there is a wide- spread necrotizing arteritis, with bound viral antigen, immunoglobulin, and complement in blood vessel walls. It seems likely that this follows local multiplication of virus rather than secondary deposition of circulating immune complexes. Thus factors other than the presence of complexes in the circulation determine their localization and the severity of the immunopathological reactions which they produce.

One of the interesting associations to emerge during the past few years has been the presence of Australia antigen in about $60 \%$ of patients with periarteritis nodosa (Trepo and Thivolet, 1970; Gocke, Hsu, Morgan, Bombardieri, Lockshin, and Christian, 1971). In five fatal cases of hepatitis, Australia antigen, immunoglobulin, and complement were found in the intima of arterioles showing changes typical of periarteritis (Nowosławski, Brzosko, Krawczyński, and Madaleński, 1972). A case of immune complex nephritis has been reported with deposition of Australia antigen, IgG, and complement in the glomeruli (Combes, Stastny, Shorey, Eigenbrodt, Barrera, Hull, and Carter, 1971) and at necropsy of four fatal cases of hepatitis Australia antigen, $\operatorname{IgG}, \operatorname{IgM}$, and complement were found in glomerular capillaries (Nowosławski et al, 1972). From observations on synovial tissues, Alpert et al (1971) suggest that immune complexes with Australia antigen contribute to the urticaria and arthritis sometimes associated with hepatitis.

\section{Hypersensitivity in Virus Infections}

Reports of local and systemic reactions in recipients of inactivated measles vaccine when subsequently inoculated with live virus vaccine (Buser, 1967; Scott and Bonanno, 1967) or experiencing natural infection (Nader, Horwitz, and Rousseau, 1968) suggest the importance of hypersensitivity reactions in virus infections. In the vaccinated subjects atypical exanthema and swelling and erythema at the site of infection developed over three to eight days. Evidence that this is an Arthus-type reaction has been presented by Bellanti, Sanga, Klutinis, Brandt, and Artenstein (1969), who found bound immunoglobulin, measles antigen, and complement components in skin biopsies from the sites of local reaction.

Chanock, Parrott, Kapikian, Kim, and Brandt (1968) have proposed a similar explanation for the severity of respiratory syncytial virus infection in babies. Lack of secretory antibody (which is not received from the mother) would allow establishment of a local infection, and circulating maternal IgG antibody could form complexes with virus antigen in the pulmonary tissue and produce an Arthus reaction. 


\section{Scrapie}

Although the agent producing scrapie is classified as a slow virus, it shows many remarkable properties, including extreme resistance to radiation (Latarjet, Muel, Haig, Clarke, and Alper, 1970) and apparent absence of immunogenicity. No antibody has been demonstrable by neutralization, complement fixation, precipitation, or immunofluorescence (Gibbs, Gajdusek, and Morris, 1965; Chandler, 1959). There are no mononuclear infiltrates of lesions suggestive of a cell-mediated immune response. Neonatal thymectomy (Gibbons and Hunter, 1967) or thymectomy, lethal irradiation, and reconstitution with foetal liver cells, which markedly depletes thymusderived $(T)$ lymphocytes, had no effect on the incubation period or pathology of scrapie in mice (McFarlin, Raff, Simpson, and Nehlsen, 1971). This suggests that cell-mediated immunity neither contributes to the pathogenesis of scrapie nor plays a significant role in the host's defence against the agent.

\section{Equine Infectious Anaemia}

This disease is restricted to Equidae and is characterized by persistence of virus, haemolytic anaemia with C3-coated erythrocytes, hypergammaglobulinaemia, deposition of $\gamma$-globulin and $\mathrm{C} 3$ in the renal glomeruli (Banks and Henson, 1969), and decreased circulating $\mathrm{C} 3$ levels. The clinical course is variable; some horses have severe haemolytic disease while others become asymptomatic. Infected horses remain viraemic for life, despite the presence of neutralizing and complement-fixing antibody in the serum (McGuire, Crawford, and Henson, 1971). By immunofluorescence viral antigen is demonstrable in the cytoplasm of peripheral blood leucocytes, macrophages lining blood or lymph sinuses, and other sites. The virus thus apparently replicates in macrophages. The anaemia may result from attachment of viral antigen-antibody-complement complexes to erythrocytes, with their subsequent removal from the circulation.

\section{Aleutian Mink Disease}

Aleutian disease is a chronic virus infection of mink, which has caused serious economic losses to commercial ranchers. 'Mutation' mink homozygous for a pale coat colour (Aleutian) gene are particularly susceptible to the disease but other mink also develop chronic infections. Once the infection is established, virus can be recovered from the serum, organs, and urine for the remainder of the animal's life. The primary lesion is a systemic proliferation of plasma cells, and this is associated with marked hyper- gammaglobulinaemia, sometimes of monoclonal (myeloma-like) nature. Glomerulonephritis, degenerative arterial lesions, and proliferation of intrahepatic bile ducts are commonly seen.

Porter et al (1969) have shown that Aleutian disease virus replicates rapidly, and attains high titres, especially in the liver. Viral antigen is confined to the cytoplasm of macrophages in spleen and lymph nodes and Küpffer cells in the liver. Very high levels of antibodies (measured by indirect immunofluorescence against viral antigen) were found. Secondary deposits of viral antigen, antibody, and complement are marked in the renal glomeruli where they exhibit the bumpy appearance characteristic of immune complexes. Bound immunoglobulin and complement have also been found in arteriolar walls.

\section{Lactic Dehydrogenase Virus}

This is a virus infection of mice which, once established in newborn or adult animals, persists for life. Infectious virus continues to circulate in the plasma. It is combined with antibody and can be neutralized by antiserum against mouse immunoglobulin (Notkins, Mahar, Scheele, and Goffman, 1966). The virus replicates in macrophages (Evans and Salaman, 1965). Immune complexes are found in the kidneys (Porter and Porter, 1971), but they are much less striking than in lymphocytic choriomeningitis virus. Whether a cell-mediated immune response is mounted against this virus has not been investigated.

\section{Visna-maedi}

Dr Pálsson describes elsewhere in the present volume this complex of progressive infections of the central nervous system and lungs of sheep. Relevant to the present discussion is the fact that virus infection continues to spread despite the presence of neutralizing antibody in serum. Possibly cellmediated immunity plays a part in controlling this myxovirus-like agent (as in measles) and in Icelandic sheep specific cell-mediated immunity is ineffective. A deliberate search for cell-mediated immunity, using virus-infected cells, and for blocking serum factors would be well worth while. Since virus is readily recovered from mononuclear cells in cerebrospinal fluid, most of which are macrophages, virus may be able to replicate in macrophages. Since this would contribute to the persistent infection despite the presence of antibody, it would be worth investigating systematically.

\section{Measles and Subacute Sclerosing Panencephalitis (SSPE)}

Subacute sclerosing panencephalitis is a slow infec- 
tion of the central nervous system of children with measles virus (see Connolly, this symposium). In view of the evidence summarized in the section on cell-mediated immunity that this reaction plays an important part in controlling measles infections, one possible explanation for persistent measles infection of the central nervous system would be that the patient has a generalized deficit of cell-mediated immunity or a specific deficit in cell-mediated immunity directed against viral antigens on infected cells. Presumably these would be envelope rather than nucleoprotein antigens. The limited evidence which has been published is conflicting.

It has long been known that measles infections temporarily suppress cell-mediated immune reactions against unrelated antigens, eg, tuberculin; this is true of infections with vaccine as well as naturally occurring strains of the virus. However, patients usually recover their capacity to produce delayed hypersensitivity within a few weeks.

Kolar (1968) described a reduced lymphocyte response to phytohaemagglutinin in two patients with subacute sclerosing panencephalitis. Gerson and Haslam (1971) reported that four boys with SSPE had impaired expression of delayed hypersensitivity to skin test antigens and delayed rejection of skin allografts. In three of the four IgA levels were subnormal. In contrast, Jabbour, Roane, and Sever (1969) found that all eight SSPE patients tested had positive skin responses to Candida; two of three patients tested became sensitized to dinitrochlorobenzene. Skin tests with measles antigen (at best a procedure difficult to interpret) were negative. Saunders, Knowles, Chambers, Caspary, GardnerMedwin, and Walker (1969) not only found a normal lymphocyte response to phytohaemagglutinin in one patient with SSPE but state that transformation of lymphocytes in the presence of measles antigen was increased. Dr M. J. Dillon and Professor J. F. Soothill (Institute of Child Health) have found normal lymphocyte transformation by phytohaemagglutinin in eight cases of SSPE (private communication). Thus there is at present no consistent evidence for an overall impairment of cellmediated immunity in SSPE, or of an absence of reaction to measles antigen. Evidence on the latter point is, however, weak. Attempts should be made to obtain consistent stimulation in vitro of lymphocytes from convalescent subjects with measles virusinfected cells. These could then be compared with responses from SSPE patients, and tests could also be made for blocking factors in SSPE serum.

We have observed a condition like SSPE but with progressive blindness as well in two related boys with combined immunodeficiency syndromes, including marked deficiency of all immunoglobulin classes.
Electron micrographs of the brain of one patient who died, taken by Dr A. Dayan, showed numerous intranuclear structures indistinguishable from measles nucleocapsids. The second child is still under investigation and details will be published elsewhere. Thus severe SSPE-like neuropathology may occur as a complication of immunodeficiency.

An interesting animal model has been described by Wear and Rapp (1971). Human measles virus adapted to hamster brain replicated to high titres and produced encephalitis when inoculated into unprotected newborn hamsters. However, measles antibodies acquired from immunized mothers blocked acute encephalitis but not intracellular virus replication in the central nervous system. The infection remained latent until the animals were treated with cyclophosphamide, when the majority developed persistent myoclonic tremors. Virus was isolated from these animals for at least $\mathbf{9 0}$ days after infection. These observations suggest that maternally acquired antibody suppresses but does not eliminate the virus infection, and that the latent virus can be reactivated by immunosuppressive treatment. Whether the activation is due to effects on specifically sensitized lymphocytes is not yet clear.

\section{Varicella Zoster}

It is now generally accepted that the same virus causes varicella or chickenpox and herpes zoster (see McCarthy, this symposium). The latter might be due to the persistence of varicella-zoster virus in a latent form following chickenpox infection or it might be due to reinfection. Miller and Brunell (1970) have summarized reasons for supporting the former view. An epidemiological investigation of 108 patients with zoster showed that (1) only four had a possible recent exposure to varicella or zoster; (2) there was no increase in zoster cases corresponding to the seasonal peak of varicella; and (3) the fewest cases of zoster were contributed by subjects with the greatest likelihood of being exposed to varicella. Subjects with varicella have a primary immune response, with both IgM and IgG antibodies against viral antigens, whereas those with zoster have a secondary response, with only IgG antibodies (Leonard, Schmidt, and Lennette, 1970).

Thus available evidence suggests that varicellazoster virus can remain latent in the body after chickenpox infection, and can emerge when host resistance wanes. In considering resistance against the virus, it appears that there are two components. Antibody can protect against the initial infection. Immune globulin from zoster patients has been found, in double-blind studies, to prevent varicella in exposed children (Brunell, Ross, Miller, and Kuo, 
1969). However, once the infection has become established, administration of antiviral antibody has no real beneficial effect. Patients develop localized zoster despite rapid rises in levels of antibody against the virus in peripheral blood, and the same is true of most patients with generalized zoster. Two patients with cytotoxic therapy for malignant disease had delayed antibody responses, but this may have been part of a widespread deficit in their immune responses. A mother developed zoster one month following the birth of twin. (Gibbs, Shapiro, Cassidy, and Brunell, 1970). The twins were not infected although their 4-year-old sibling developed varicella following exposure to the mother. Gibbs and his colleagues conclude that although maternal antibody synthesis was sufficient to protect her twins by passive transfer across the placenta, it was insufficient to protect her against reactivation of a latent varicella-zoster virus infection.

It seems likely that the most effective defence mechanism once varicella-zoster virus infection has become established is cell-mediated immunity. $\mathrm{Dr}$ P. A. Brunell, who is spending a sabbatical year with us, has found that lymphocytes of subjects convalescing from varicella show marked stimulation of DNA synthesis in the presence of varicella-infected cells, but not uninfected control cells. Sonicates of infected cells stimulated the lymphocytes much less well. This should enable us to establish whether the specific cell-mediated immune response against varicella antigens on infected cells is depressed in patients with zoster. Many such patients, especially those with lymphomas and other malignant diseases treated with cytotoxic drugs, have non-selective depression of lymphocyte reactivity (decreased skin reactions to test antigens and in vitro response to mitogens-see Rifkind, 1966). The possibility that varicella antigen-antibody complexes or other serum factors specifically block the effects of lymphocytemediated immunity is also worth investigating.

\section{Cytomegalovirus}

Host-specific cytomegaloviruses establish latent infections in man and many other mammals, including the monkey, guinea pig, rat, hamster, and mouse. Serological surveys show that more than $80 \%$ of human subjects above the age of 35 have been infected with cytomegalovirus. Normally, disease (of the liver and brain) is produced only in infants with congenital infections, possibly from mothers with primary subclinical infections during pregnancy. The virus may remain latent in salivary gland and other tissues and emerge after immunosuppressive treatment both in guinea pigs (Smith and Vellios, 1950) and in man (Cangir and Sullivan, 1966; Craighead,
1969). Cytomegalovirus infections have been troublesome in renal transplant patients (Montgomerie et al, 1969) and in patients with renal lymphoreticular malignancies treated with cytotoxic drugs. The experimental animals and human subjects in which cytomegalovirus infections are activated may have serum antibody against the virus, suggesting again that serum antibody alone is insufficient to control the infection.

\section{Comment}

Some tentative generalizations can be made about the immunology of persistent virus infections.

1 With scrapie, mink encephalopathy, kuru, and Creutzfeld-Jacob disease there does not appear to be a host immune response at all, although in at least some cases the agent transmitting the disease is found in high titre in the lymphoreticular system. Hence immunological factors neither control nor complicate the disease.

2 Certain virus infections, once established, are never eliminated, and viraemia persists until the death of the host. This is true, for example, of Aleutian mink disease, equine infectious anaemia, and lactic dehydrogenase virus infection of mice, all established in adult animals, and of murine infections with certain leukaemogenic viruses or lymphocytic choriomeningitis established in newborn mice. Sometimes (as in Aleutian mink disease and equine infectious anaemia) this is accompanied by hypergammaglobulinaemia and high levels of antiviral antibody. Often virus circulates in the form of complexes with antibody which are still infectious, but which can be rendered non-infectious by treatment with antiglobulin serum. Complexes of viral antigen and antibody are deposited in the renal glomeruli or arterial walls, giving rise to glomerulonephritis and panarteritis. With lactic dehydrogenase virus, this complication is slight; with Aleutian mink disease, equine infectious anaemia, lymphocytic choriomeningitis, and leukaemogenic viruses under certain conditions it is severe. Human hepatitis virus infections are occasionally accompanied by periarteritis, with Australia antigen and antibody in the blood vessel walls, and immune complexes are occasionally found in renal glomeruli.

Why some of these virus infections can persist in the presence of high levels of neutralizing antibody in the serum is not yet understood. One factor may be the ability of some of the viruses in question (eg, Aleutian mink disease, equine infectious anaemia, lactic dehydrogenase virus, LCM) to replicate in macrophages, including Küpffer cells and cells lining splenic sinuses. Possibly complexes of virus and antibody removed from the circulation by 
macrophages multiply in these cells without destroying them. The other distinctive property of viruses in this group is that they do not kill the cells in which they replicate. The lesions which they produce are largely immunopathological.

3 Viruses which remain latent for long periods and may then be reactivated include herpesviruses (herpes simplex and varicella-zoster) and measles (in subacute sclerosing panencephalitis). These viruses probably remain latent in the nervous system and cell-mediated immunity plays a major part in controlling their spread, which occurs in the presence of neutralizing antibody. Diminution of the effectiveness of cell-mediated immunity against the virus (because of depression of $\mathrm{T}$ cell-mediated responses, either general or virus-specific) probably allows reactivation of the infection, although the observations so far made on these points are by no means definitive.

\section{References}

Allison, A. C. (1972a). Immunity against viruses. Sci. Basis Med. Anu. Rev., pp. 49-73.

Allison, A. C. (1972b). The role of membranes in the replication of animal viruses. Int. Rev. exp. Path., in press.

Allison, A. C., Denman, A. M., and Barnes, R. D. (1971). Cooperating and controlling functions of thymus-derived lymphocytes in relation to autoimmunity. Lancet, 2, 135-140.

Alpert, E., Isselbacher, K. J., and Schur, P. H. (1971). The pathogenesis of arthritis associated with viral hepatitis. Complementcomponent studies. New Engl. J. Med., 285, 185-189.

Banks, K. L., and Henson, J. B. (1969). Glomerular deposition of gamma globulin and complement $\left(C^{\prime} 3\right)$ in equine infectious anemia. Fed. Proc., 28, 752.

Bellanti, J. A., Sanga, R. L., Klutinis, B., Brandt, B., and Artenstein, M. S. (1969). Antibody responses in serum and nasal secretions of children immunized with inactivated and attenuated measlesvirus vaccines. New Engl.J. Med., 280, 628-633.

Blanden, R. V. (1970). Mechanisms of recovery from a generalized virus infection: mousepox. 1. The effects of anti-thymocyte serum.J. exp. Med., 132, 1035-1054.

Bloom, B. R., Jimenez, L., and Marcus, P. I. (1970). A plague assay for enumerating antigen-sensitive cells in delayed type hypersensitivity. J. exp. Med., 132, 16-30.

Brier, A. M., Wohlenberg, C., Rosenthal, J., Mage, M., and Notkins, A. L. (1972). Inhibition or enhancement of immunological injury of virus-infected cells. Proc. nat. Acad. Sci. (Wash.), in the press.

Brunell, P. A., Ross, A., Miller, L. H., and Kuo, B. (1969). Prevention of varicella by zoster immune globulin New Engl. J. Med., 280, $1191-1194$.

Buser, F. (1967). Side reaction to measles vaccination suggesting the Arthus phenomenon. New Engl. J. Med., 277, 250-251.

Chandler, R. L. (1959). Attempts to demonstrate antibodies in scrapie disease. Vet. Rec., 71, 58-59.

Cangir, A., and Sullivan, M. P. (1966). The occurrence of cytomegalovirus infections in childhood leukemia. J. Amer. med. Ass. 195, 616-622.

Chanock, R. M., Parrott, R. H., Kapikian, A. Z., Kim, H. W., and Brandt, C. D. (1968). Possible role of immunological factors in pathogenesis of RS virus lower respiratory tract disease. Perspect. Virol., 6, 125-139.

Cole, G. A., Gilden, D. H., Monjan, A. A., and Nathanson, N. (1971). Lymphocytic choriomeningitis virus: pathogenesis of acute central nervous system disease. Fed. Proc., 30, 1831-1841.

Combes, B., Stastny, P., Shorey, J., Eigenbrodt, E. H., Barrera, A. Hull, A. R., and Carter, N. W. (1971). Glomerulonephritis with deposition of Australia antigen-antibody complexes in glomerular basement membra ne. Lancet, 2, 234-237.

Cooper, M. D., Chase, H. P., Lowman, J. T., Krivit, W., and Good,
R. A. (1968). Wiskott-Aldrich syndrome. An immunologic deficiency disease involving the afferent limb of immunity. Amer. J. Med., 44, 499-513.

Craighead, J. E. (1969). Immunologic response to cytomegalovirus infection in renal allograft recipients. Amer. J. Epidemiol., 90, 506-513.

Deforest. A., and Klein, M. (1968). The immunoglobulin response in recurrent herpes simplex infection in man. Fed. Proc., 27, 734

Dixon, F. J., Oldstone, M. B. A., and Tonietti, G. (1971). Pathogenesis of immune complex glomerulonephritis of New Zealand mice. J. exp. Med., 134, 65s-71s.

Ellison, S. A., Carton, C. A., and Rose, H. M. (1959). Studies of recurrent herpes simplex infections following section of the trigeminal nerve. J. infect. Dis., 105, 161-167.

Evans, R., and Salaman, M. H. (1965). Studies on the mechanism of action of Riley virus. III. Replication of Riley's plasma enzyme-elevating virus in vitro. J. exp. Med., 122, 993-1002.

Fulginiti, V. A., Kempe, C. H., Hathaway, W. E., Pearlman, D. S. Sieber, O. F., Eller, J. J., Joyner, J. W., and Robinson, A. (1968). Progressive vaccinia in immunologically deficient individuals. In Immunologic Deficiency Diseases in Man (Birth Defects: Original Article Series, vol. 4, no. 1) edited by D. Bergsma, pp. 128-151. National Foundation, Washington D.C.

Gerson, K. L., and Haslam, R. H. A. (1971). Subtle immunologic abnormalities in four boys with subacute sclerosing panencephalitis. New Engl. J. Med., 285, 78-82.

Gibbons, R. A., and Hunter, G. D. (1967). Nature of the scrapie agent. Nature (Lond.), 215, 1041-1043.

Gibbs, C. J. Jr., Gajdusek, D. C., and Morris, J. A. (1965). Vira characteristics of the scrapie agent in mice. In Slow, patent, and Temperate Virus Infections (NINDB Monograph, no. 2), edited by D. C. Gajdusek, C. J., Gibbs, Jr., and M. Alpers, pp. 192-202. National Institute of Neurological Diseases and Blindness, Washington, D.C.

Gibbs, R. C., Shapiro, E., Cassidy, H., and Brunell, P. A. (1970) Possible mechanisms for maintaining immunity to varicellazoster virus. Amer. J. Dis. Child., 120, 456-457.

Glasgow, L. A. (1970). Interrelationships of interferon and immunity during viral infections. J. gen. Physiol., 56, Suppl. (July), 212 s$226 \mathrm{~s}$

Gocke, D. J., Hsu, K., Morgan, C., Bombardieri, S., Lockshin, M. and Christian, C. L. (1971). Vasculitis in association with Australia antigen. J. exp. Med., 134, 330s.

Gudnadóttir, M., and Pálssón, P. A. (1965). Host-virus interaction in visna-infected sheep. J. Immunol., 95, 1116-1120.

Haworth, J. C., Hoogstraten, J., and Taylor, H. (1967). Thymic alymphoplasia. Arch. Dis. Childh., 42, 40-54.

Hayes, J. A., Been, T. E., Valentine, E. J., and Bras, G. (1965). A case of fatal dissemination of varicella. J. Path. Bact., 90, 328333.

Jabbour, J. T., Roane, J. A., and Sever, J. L. (1969). Studies of delayed dermal sensitivity in patients with subacute sclerosing panencephalitis. Neurology (Minneap.), 19, 929-931.

Johnson, R. T. (1964). The pathogenesis of herpes virus encephalitis 1. Virus pathways to the nervous system of suckling mice demonstrated by fluorescent antibody staining. J. exp. Med., 119, 343-357.

Kaufman, H. E., Brown, D. C., and Ellison, E. M. (1967). Recurrent herpes in the rabbit and man. Science, 156, 1628-1629.

Kolar, O. (1968). Measles and subacute sclerosing panencephalitis. Lancet, 2, 1242.

Kretschmer, R., August, C. S., Rosen, F. S., and Janeway, C. A. (1969). Recurrent infections, episodic lymphopenia and impaired cellular immunity. New Engl. J. Med., 281, 285-290.

Latarjet, R., Muel, B., Haig, D. A., Clarke, M. C., and Alper, T. (1970). Inactivation of the scrapie agent by near monochromatic ultraviolet light. Nature (Lond.), 227, 1341-1343.

Lehmann-Grubbe, F. (1971). Lymphocytic Choriomeningitis Virus (Virology Monographs, Vol. 10). Springer-Verlag, Vienna and New York.

Leonard, L. L., Schmidt, N. J., and Lennette, E. H. (1970). Demonstration of viral antibody in two immunoglobulin $G$ subclasses in patients with varicella-zoster virus infection. $J$. Immunol., 104, 23-27.

Lundstedt, C. (1969). Interaction between antigenically different cells: virus-induced cytotoxicity by immune lymphoid cells in vitro. Acta path. microbiol. scand., 75, 139-152.

Lux, S. E., Johnston, R. B., Jr., August, C. S., Say, B., Penchaszadeh, V. B., Rosen, F. S., and McKusick V. A. (1970). Chronic 
neutropenia and abnormal cellular immunity in cartilage-hair hypoplasia. New Engl. J. Med., 282, 231-236.

McFarlin, D. E., Raff, M. C., Simpson, E., and Nehlsen, S. H. (1971). Scrapie in immunologically deficient mice. Nature (Lond.), 233, 336.

McGuire, T. C., Crawford, T. B., and Henson, J. B. (1971). Immunofluorescent localization of equine infectious anemia virus in tissue. Amer. J. Path., 62, 283-294.

Miller, L. H., and Brunell, P. A. (1970). Zoster, reinfection or activation of a latent virus? Amer. J. Med., 49, 480-483.

Miller, M. E., and Schieken, R. M. (1967). Thymic dysplasia. A separable entity from 'Swiss agammaglobulinemia'. Amer. $J$. med. Sci., 253, 741-750.

Montgomerie, J. Z., Becroft, D. M. O., Croxson, M. C., Doak, P. B., and North, J. D. K. (1969). Herpes-simplex-virus infection after renal transplantation. Lancet, 2, 867-871.

Nader, R. P., Horwitz, M. S., and Rousseau, J. (1968). Atypical exanthem following exposure to natural measles: eleven cases in children previously inoculated with killed vaccine. J. Pediat., 72, 22-28.

Nahmias, A., Griffith, D., Salsbury, C., and Yoshida, K. (1967). Thymic aplasia with lymphopenia, plasma cells, and normal immunoglobulins: relation to measles virus infection. J. Amer. med. Assc., 201, 729-734.

Nathanson, N., and Cole, G. A. (1970). Immunosuppression and experimental virus infection of the nervous system. Advanc. virus Res., 16, 397-448.

Notkins, A. L., Mahar, S., Scheele, C., and Goffman, J. (1966). Infectious virus-antibody complex in the blood of chronically infected mice. J. exp. Med., 124, 81-97.

Nowosławski, A., Brzosko, W. J., Krawczyński, K., and Madaleński, K. (1972). Australia antigen and hepatitis. Pathogenic considerations and practical implications. Rec. Advanc. clin. Path., in press.

O'Connell, C. J., Karzon, D. T., Barron, A. L., Plaut, M. E., and Ali, V. M. (1964). Progressive vaccinia with normal antibodies: a case possibly due to deficient cellular immunity. Ann. intern. Med., 60, 282-289.

Oldstone, M. B. A., and Dixon, F. J. (1969). Pathogenesis of chronic disease associated with persistent lymphocytic choriomeningitis viral infection. 1. Relationship of antibody production to disease in neonatally infected mice. J. exp. Med., 129, 483-505.

Oldstone, M. B. A., and Dixon, F. J. (1971). Immune complex disease in chronic viral infections. J. exp. Med., 134, 32s-40s.

Porter, D. D., Larsen, A. E., and Porter, H. G. (1969). The pathogenesis of Aleutian disease of mink. 1. In vivo viral replication and the host antibody response to viral antigen. J. exp. Med., 130, 575-593.

Porter, D. D., and Porter, H. G. (1971). Deposition of immune complexes in the kidneys of mice infected with lactic dehydrogenase virus. J. Immunol., 106, 1264-1266.

Rifkind, D. (1966). The activation of varicella-zoster virus infections by immunosuppressive therapy. J. Lab. clin. Med., 68, 463-474.

Saunders, M., Knowles, M., Chambers, M. E., Caspary, E. A., Gardner-Medwin. D., and Walker, P. (1969). Cellular and humoral responses to measles in subacute sclerosing panencephalitis. Lancet, 1, 72-74

Schur, P. H., Borel, H., Gelfand, E. W., Alper, C. A., and Rosen, F. S. (1970). Selective gamma-G globulin deficiencies in patients with recurrent pyogenic infections. New Engl. J. Med., 283 , 631-634.

Scott, T. F. M., and Bonanno, D. E.(1967). Reactions to live-measlesvirus vaccine in children previously inoculated with killed virus-vaccine. New Engl. J. Med., 277, 248-250

Smith, M. G., and Vellios, F. (1950). Inclusion disease or generalized salivary gland virus infection. Arch. Path., 50, 862-884.

Speel, L. F., Osborn, J. E., and Walker, D. L. (1968). An immunocytopathogenic interaction between sensitized leukocytes and epithelial cells carrying a persistent noncytocidal myxovirus infection. J. Immunol., 101, 409-417.

Stevens, J. G., Nesburn, A. B., and Cook, M. L. (1972). Latent herpes simplex virus from trigeminal ganglia of rabbits with recurrent eye infection. Nature [new Biol.], 235, 216-217.

Taylor, R. B., Duffus, W. P. H. Raff, M. C and de Petris, S. (1971). Redistribution and pinocytosis of lymphocyte surface immunoglobulin molecules induced by anti-immunoglobulin antibody. Nature [new Biol.], 233, 225-229.

Trepo, C., and Thivolet, J. (1970). Hepatitisassociated antigen and periarteritis nodosa (PAN). Vox Sang. (Basel), 19, 410-411.

Wear, D. J., and Rapp, F. (1971). Latent measles virus infection of the hamster central nervous system. J. Immunol., 107, 1593-1598.

Webb, H. E. (1969). The pathogenesis of the viral encephalitides. In Virus Diseases and the Nervous System, edited by C. W. M. Whitty, J. T. Hughes, and F. O. MacCallum, pp. 169-177. Blackwell, Oxford.

Weiner, L. P., Cole, G. A., and Nathanson, N. (1971). Virus-specific immunologic depression in mice following combined immunization and cyclophosphamide-induced immunosuppression. J. Immunol., 106, 427-430.

Wiktor, T. J., Kuwert, E., and Koprowski, H. (1968). Immune lysis of rabies virus-infected cells. J. Immunol., 101, 1271-1282.

Zisman, B., Wheelock, E. F., and Allison, A. C. (1971). Role of macrophages and antibody in resistance of mice against yellow fever virus. J. Immunol., 107, 236-243.

Zlotnik, I., Smith, C. E. G., Grant, D. P., and Peacock, S. (1970). The effect of immunosuppression on viral encephalitis, with special reference to cyclophosphamide. Brit. J. exp. Path., 51, 434-439. 